\title{
Synthesis of 3-indolylazoles and meridianin derivatives from indolyl enaminonitriles
}

\author{
Ana M. F. Oliveira-Campos, ${ }^{\text {a }}$ Abdellatif M. Salaheldin, ${ }^{\text {a }}$ Filipe A. Almeida Paz, \\ and Ligia M. Rodrigues ${ }^{\mathrm{a}}$ \\ ${ }^{a}$ Centro de Química, Universidade do Minho, Campus de Gualtar, 4710-057 Braga, Portugal \\ ${ }^{b}$ Department of Chemistry, CICECO, University of Aveiro, Campus Universitário de Santiago, \\ 3810-193 Aveiro, Portugal \\ E-mail: amcampos@quimica.uminho.pt
}

\begin{abstract}
The reaction of indole derivatives with cyanoacetic acid followed by treatment with DMFDMA gave the intermediate indolyl enaminonitriles 3. Further reaction with aminoguanidine yielded $5^{\prime}$-cyanomeridianin analogues 4 . The same intermediate reacted with $p$-methoxyphenylhydrazine to give the pyrazolyl derivative $\mathbf{8}$.

Treatment of (2E)-3-dimethylamino-2-(1H-indol-3-yl)-propenoate $3 \mathbf{a}$ with hydroxylamine hydrochloride in basic medium afforded (5-amino-isoxazol-4-yl)-(1H-indol-3-yl)-methanone 5 and the acrylic acid derivative $\mathbf{6}$ after a short or a long heating, respectively. Unequivocal structural elucidation of the latter compound was achieved from single-crystal X-ray diffraction studies.
\end{abstract}

Keywords: Indole, alkaloids, enaminonitrile, meridianins, 3-indolylazoles

\section{Introduction}

Enaminonitriles are versatile reagents which have been efficiently utilized for the synthesis of heteroaromatics. ${ }^{1}$ Meridianin alkaloids, isolated from the south atlantic tunicate Aplidium meridianum, ${ }^{2}$ are indole derivatives substituted at the $\mathrm{C}-3$ position by a 2 -aminopyrimidine ring. Since abnormal protein phosphorylation is related to many human diseases interest on the search for inhibitors of kinases has increased. A vast number of inhibitors of CDKs have been discovered, however, only very few GSK-3 inhibitors have been described.

Meridianins $^{2-4}$ (Figure 1) were described as potent kinase inhibitors, ${ }^{4}$ inhibiting CDKs, GSK-3, PKA and other protein kinases in the low micromolar range. Some derivatives displayed also antitumor activity. ${ }^{5}$ 
There are three reported approaches for the synthesis of meridianins from indole derivatives based on a Suzuki cross-coupling with indole-3-boronic acid derivatives. ${ }^{6}$ A Bredereck synthesis was also described from $\beta$-enaminones, which were, in turn, obtained from 3-acetylindole derivatives. ${ }^{5,7,8}$ More recently, meridianins were also obtained from trimethylsilylynone indole derivatives. $^{9}$

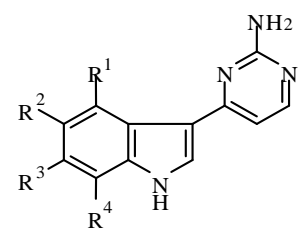

Me ridianins

$$
\begin{aligned}
& \text { A, } R^{1}=O H, R^{2}=R^{3}=R^{4}=H \\
& B, R^{1}=O H, R^{2}=R^{4}=H, R^{3}=B r \\
& C, R^{1}=R^{3}=R^{4}=H, R^{2}=B r \\
& D, R^{1}=R^{2}=R^{4}=H, R^{3}=B r \\
& E, R^{1}=O H, R^{2}=R^{3}=H, R^{4}=B r \\
& F, R_{1}^{1}=H_{2} R^{2}=R^{3}=B r, R^{4}=H
\end{aligned}
$$

$\mathrm{G}, \mathrm{R}^{1}=\mathrm{R}^{2}=\mathrm{R}^{3}=\mathrm{R}^{4}=\mathrm{H}$

Figure 1. General representation of meridianin alkaloids.

\section{Results and discussion}

Following our interest in the chemistry of $\beta$-enaminonitriles, ${ }^{10-13}$ in this manuscript we describe our most recent results that explore the potential of 3(2E)-3-dimethylamino-2-(1H-indol-3-yl)propenoate in the synthesis of 5'-cyanomeridianin $\mathrm{C}, \mathrm{G}$ and 3-heteroarylindoles. Commercially available indole and indole-3-carboxaldehyde were employed as the starting materials giving access to the meridianin analogs $\mathbf{4 a - c}$ in a straightforward three-step synthesis following the Bredereck approach $^{7}$ (Scheme 1), and to $\mathbf{1 4}$ from one-pot synthesis as shown in Scheme 3.

Recently, a facile procedure for the cyanoacetylation of indoles leading to compounds $\mathbf{2 a - c}$ has been reported. ${ }^{14}$ This one-step approach, applying cyanoacetic acid in acetic anhydride for the inclusion of the cyanoacetyl functionality, provides an easy access to cyanoacetylated indoles 2a-c. The Bredereck protocol ${ }^{7}$ was used for the formation of the 2-aminopyrimidine ring. When compounds 2a-c were treated with dimethylformamide dimethylacetal (DMFDMA), ${ }^{15}$ without solvent at room temperature, the corresponding enaminonitriles 3a-c were obtained in yields ranging from 78 to $88 \%$.

Direct conversion of 3a-c into 5'-cyano meridianin $\mathrm{C}$ and meridianin $\mathrm{G}$ derivatives 4a-c, involving the formation of the 2-aminopyrimidine ring, was achieved in $70-78 \%$ by treatment with guanidine hydrochloride in the presence of anhydrous potassium carbonate (Scheme 1). The structure of compounds 4a-c was established on the basis of elemental analysis, IR, mass, ${ }^{1} \mathrm{H}$ and ${ }^{13} \mathrm{C}$ NMR spectral data studies ( $c f$. Experimental Section).

Heating compound 3a for 7 hours, with hydroxylamine hydrochloride in the presence of base, did not produce the isoxazole 5, but led instead to the formation of the indole derivative $\mathbf{6}$. 


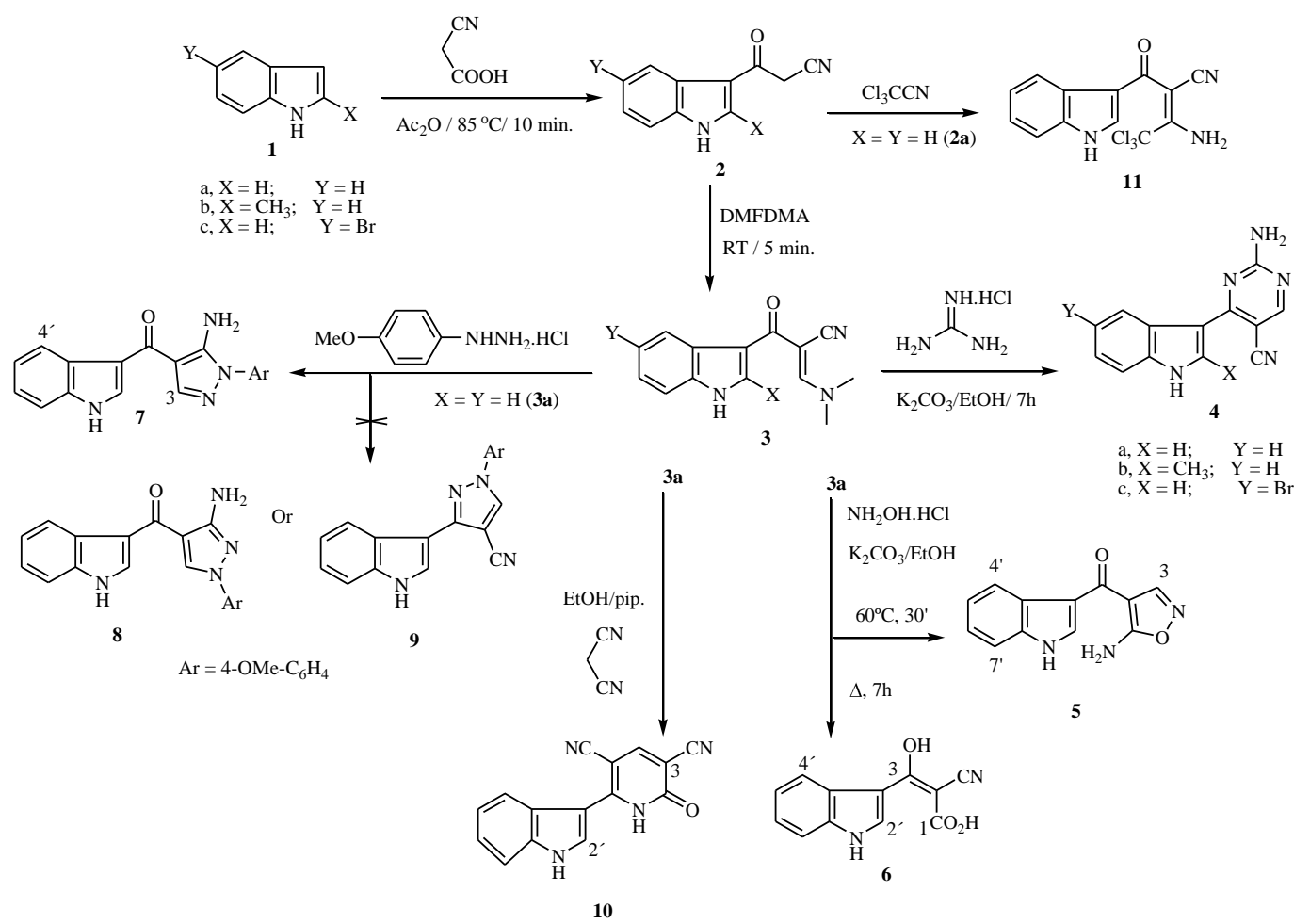

\section{Scheme 1}

The alternative structure 5 was excluded based on FT-IR and NMR data. The ${ }^{1} \mathrm{H}$ NMR spectrum of 6 showed two signals that are $\mathrm{D}_{2} \mathrm{O}$ exchangeable at 7.90 and 12.20 and a singlet for $\mathrm{H}-2$ at $8.48 \mathrm{ppm}$, while ${ }^{13} \mathrm{C}$ NMR showed a carbonyl signal at $181.55 \mathrm{ppm}$ (C-3). Unequivocal structural elucidation was achieved from single-crystal X-ray diffraction studies. Compound 6 crystallises in the centrosymmetric monoclinic $C 2 / \mathrm{c}$ space group, with the asymmetric unit being composed of a whole molecular unit (Figure 2) with typical geometrical features for the bond lengths and angles (see caption of Figure 2).

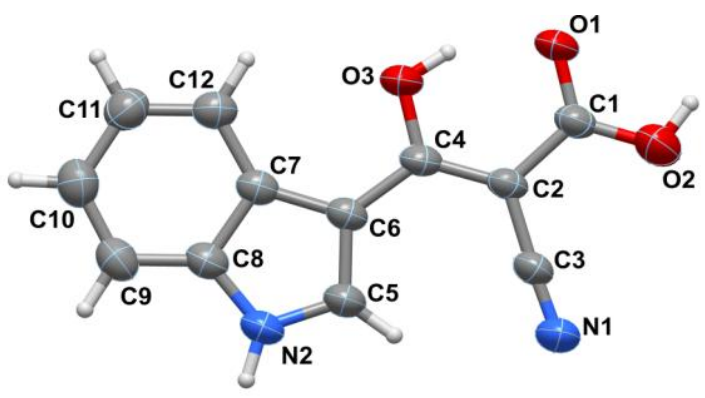

Figure 2. Schematic representation of the molecular unit of compound 6. Non-hydrogen atoms are represented as thermal ellipsoids (drawn at the $50 \%$ probability level) and hydrogen atoms as small spheres with arbitrary radii. The atomic labelling scheme is also provided for all nonhydrogen atoms. Selected bond lengths (in Å): O1-C1 1.262(2); O2-C1 1.337(3); O3-C4 
1.316(2); N1-C3 1.140(2); N2-C5 1.349(2); N2-C8 1.373(2); C1-C2 1.459(2); C2-C4 1.392(3); C2-C3 1.417(2); C4-C6 1.442(2); C5-C6 1.387(2); C6-C7 1.446(2); C7-C12 1.406(2); C7-C8 1.413(2); C8-C9 1.392(3); C9-C10 1.371(3); C10-C11 1.411(3); C11-C12 1.364(3). Selected bond angles (in degrees): C5-N2-C8 109.70(15); O1-C1-O2 120.18(16); O1-C1-C2 120.15(17); O2-C1-C2 119.66(16); C4-C2-C3 122.47(15); C4-C2-C1 120.52(15); C3-C2-C1 116.99(16); N1-C3-C2 176.64(19); O3-C4-C2 119.06(16); O3-C4-C6 113.99(16); C2-C4-C6 126.95(15); N2-C5-C6 110.16(17); C5-C6-C4 128.31(17); C5-C6-C7 105.91(15); C4-C6-C7 125.78(15); C12-C7-C8 118.12(17); C12-C7-C6 135.45(16); C8-C7-C6 106.43(15); N2-C8C9 129.18(17); N2-C8-C7 107.79(16); C9-C8-C7 123.03(17); C10-C9-C8 117.23(18); C9C10-C11 120.8(2); C12-C11-C10 121.9(2); C11-C12-C7 118.86(18).

When the reaction proceeded under mild heating conditions, for 30 minutes at $60^{\circ} \mathrm{C}$, the product isolated (26\%) was the oxazole derivative 5. The singlet due to $\mathrm{H}-3$ may be seen at 8.97 and the $\mathrm{NH}_{2}$ signal is located at $8.18 \mathrm{ppm}$ and readily exchanges with $\mathrm{D}_{2} \mathrm{O}$. It is assumed that 5 may be formed initially and with prolonged heating, in basic medium, yields 6 . Removal of the proton 3 from 5, which is known to happen in basic medium, would open the isoxazole ring to an amide whose hydrolysis would give the corresponding carboxylic acid derivative 6. Ring opening always occurs in the same fashion leading to the stereoisomer $E$ depicted in Figure 2.

This configuration has important consequences in the crystal packing as it permits the existence of a vast network composed of strong and highly directional hydrogen bonding interactions (Figure 3a): (i) the carboxylic acid groups of two neighbouring units are engaged in a typical $R^{2}{ }_{2}(8)$ graph set $\operatorname{motif}^{16}\left[\mathrm{O} 2-\mathrm{H} 2 \cdots \mathrm{O} 1^{\mathrm{i}}: d_{\mathrm{D} \cdots \mathrm{A}}\right.$ of $2.933(2) \AA$ with $<(\mathrm{DAH})$ of $c a .165^{\circ}$; symmetry code (i) $-x, 2-y,-z]$, which are reinforced by (ii) two very strong $S_{1}^{l}{ }_{1}(6)$ intramolecular motifs

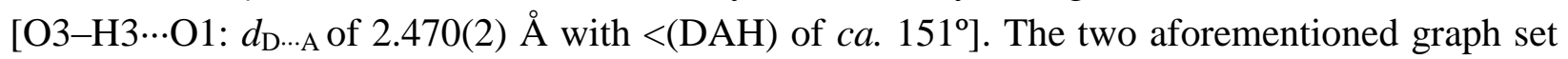
motifs promote the existence of molecular dimers within the structure (Figure 3a) which are, in turn, interconnected by way of two $\mathrm{N} 2-\mathrm{H} 2 \mathrm{~A} \cdots \mathrm{N} 1^{\mathrm{ii}}$ interactions $\left[d_{\mathrm{D} \cdots \mathrm{A}}\right.$ of $2.932(2) \AA$ with $<(\mathrm{DAH})$ of $c a \cdot 164^{\mathrm{o}}$; symmetry code (i) $\left.1 / 2-x, 2.5-y, 1-z\right]$ involving the heterocyclic $\mathrm{NH}$ moiety and the pendant $\mathrm{C} \equiv \mathrm{N}$ moiety. These interactions promote the existence of a third graph set motif, $R_{2}^{2}(16)$, which is in the genesis of the one-dimensional zigzag supramolecular tape depicted in Figure 3a. Individual tapes close pack in a typical alternate ABAB $\cdots$ fashion along the [100] direction of the unit cell mediated by the need to effectively fill the available space (Figure $3 \mathrm{~b}$ ). 


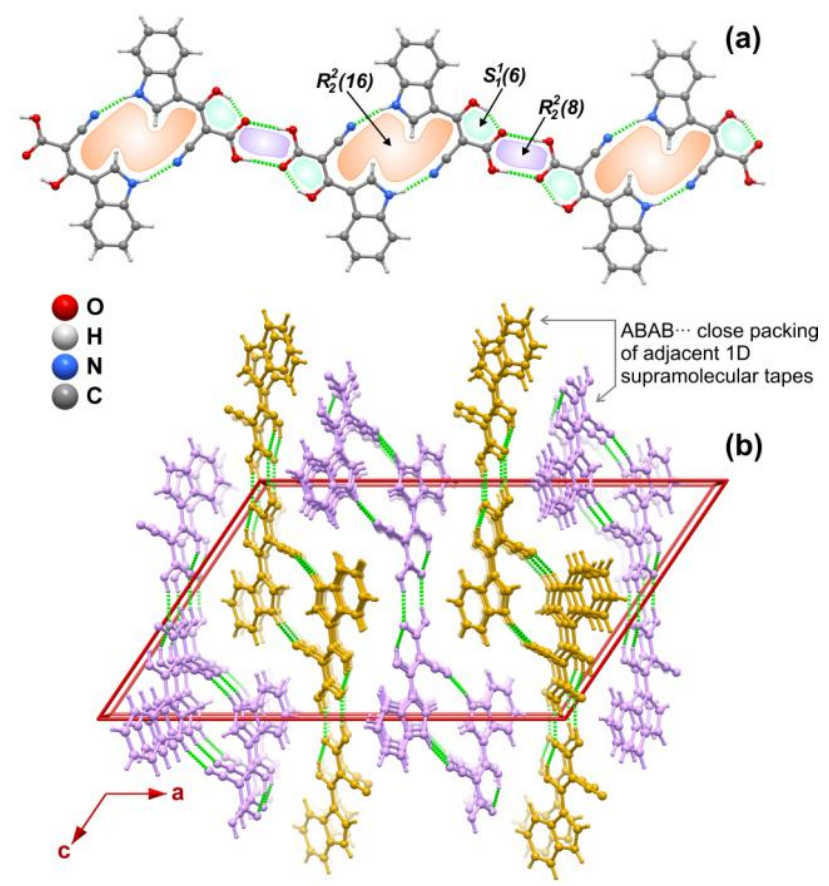

Figure 3. (a) Schematic representation of the one-dimensional zigzag supramolecular tape assembled by adjacent molecules of compound $\mathbf{6}$ engaged in strong and highly directional $(\mathrm{N}, \mathrm{O})-\mathrm{H} \cdots(\mathrm{N}, \mathrm{O})$ hydrogen bonding interactions (dashed green lines - see main text for geometrical details on the represented interactions). (b) Close packing of adjacent supramolecular tapes (represented in different colour) along the [100] direction of the unit cell depicting the actual crystal structure of compound $\mathbf{6}$.

As anticipated, the treatment of compound 3a with $p$-methoxyphenylhydrazine, in refluxing ethanol, in a basic medium, afforded as single product only pyrazole 7 (Scheme 1). The structure of the pyrazole 9 was excluded due to the absence of the typical signals of cyano groups in both the FT-IR and ${ }^{13} \mathrm{C}$ NMR spectra. The ${ }^{1} \mathrm{H}$ NMR of compound 7 showed all the expected signals which was not sufficient to differentiate between structures $\mathbf{7}$ and $\mathbf{8}$. For this reason, we collected the HMQC and HMBC NMR spectra and performed an unambiguous assignment in the ${ }^{1} \mathrm{H}$ and ${ }^{13} \mathrm{C}$ NMR spectra ( $c f$. Experimental Section). In the HMBC spectrum, no correlation peak between the pyrazole $\mathrm{H}-3$ at 8.13 ppm and carbon signals at 130.67 (C-1") was observed. This occurrence is characteristic only for structure $\mathbf{7}$ but not for $\mathbf{8} .^{17}$

Compound 3a reacted with malononitrile in the presence of piperidine as a catalyst to give $\mathbf{1 0}$ in $75 \%$ yield. The structure of compound $\mathbf{1 0}$ was readily established from ${ }^{1} \mathrm{H}$ NMR data, which revealed all the expected protons of the indole moiety alongside with a singlet at $8.59 \mathrm{ppm}$ for the $\mathrm{H}-4$ of the pyridinone ring and a NH broad signal at $13.10 \mathrm{ppm}$. Two signals due to $\mathrm{CN}$ groups were found in the ${ }^{13} \mathrm{C}$ NMR spectrum at 115.44 and $116.96 \mathrm{ppm}$. The formation of the pyridine-3,5-dicarbonitrile $\mathbf{1 0}$ from the reaction of $\mathbf{3 a}$ with malononitrile is assumed to take place through the sequence depicted in Scheme 2. 

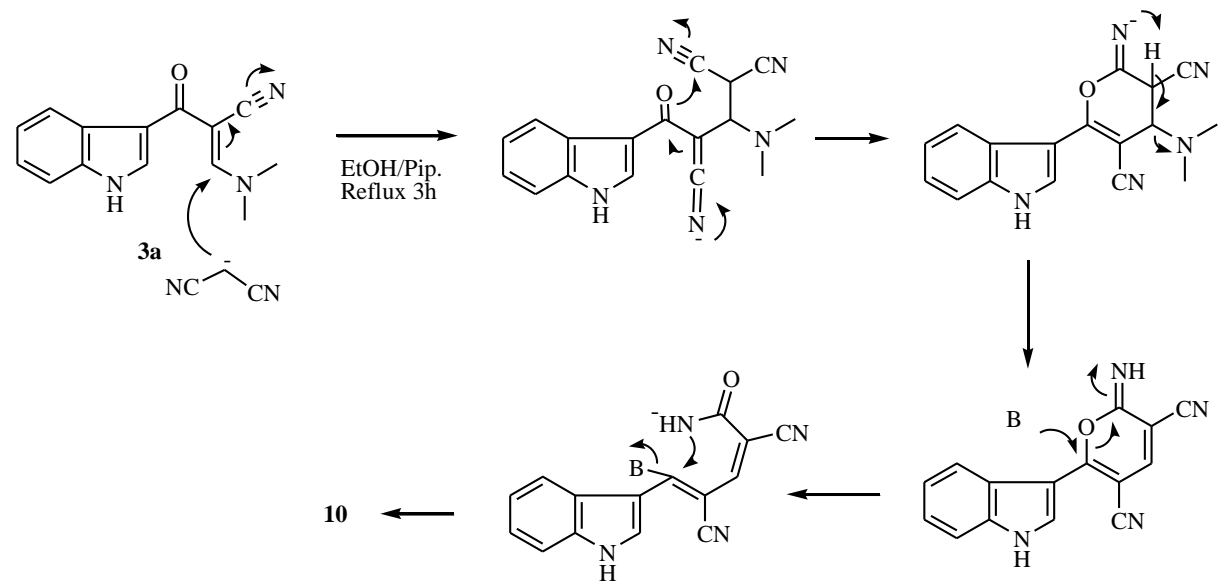

\section{Scheme 2}

The reactivity of the methylene group in compound $\mathbf{2}$ was exploited by reacting this compound with trichloroacetonitrile in ethanol in the presence of sodium acetate to obtain the new enamine 11 (Scheme 1). The structure of compound 11 was established by ${ }^{1} \mathrm{H}$ NMR data which revealed the absence of a signal for the methylene group and the emergence of another at $11.98 \mathrm{ppm}$ corresponding to two protons of the amino group.

Recently Stanovnik et al. reported the synthesis of condensed indolylpyrimidones as meridianin analogs ${ }^{18}$ and polycyclic meridianin analogs with the uracil structural unit. ${ }^{19}$ Treatment of ethyl 2-cyano-3-(1H-indol-3-yl)acrylate $\mathbf{1 3}$ with guanidine hydrochloride in the presence of anhydrous potassium carbonate in ethanol at reflux temperature affords the corresponding 2-amino-6-(1H-indol-3-yl)-4-oxo-1,4-dihydropyrimidine-5-carbonitrile $\mathbf{1 4}$ (Scheme 3).

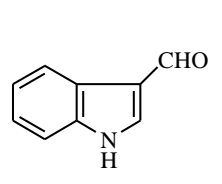

12

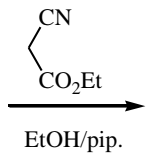

EtOH/pip.<smiles>CCOC(=O)/C=C/c1c[nH]c2ccccc12</smiles>

13

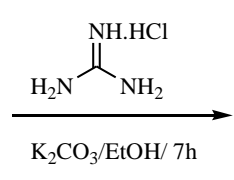

$\mathrm{K}_{2} \mathrm{CO}_{3} / \mathrm{EtOH} / 7 \mathrm{~h}$<smiles>N#Cc1c(-c2c[nH]c3ccccc23)[nH]c(N)nc1=O</smiles>

14

\section{Scheme 3}

\section{Conclusion}

Two novel indolyl enaminonitriles (3b and $\mathbf{3 c}$ ) were prepared and reacted with guanidine hydrochloride yielding two new meridianin derivatives $(\mathbf{4 b}$ and $\mathbf{4 c})$. 
The reactivity of the enaminonitrile 3a was tested with p-methoxyphenylhydrazine and malononitrile giving a pyrazole derivative 7 and a pyridone derivative 10, respectively.

The reaction of 3a with hydroxylamine hydrochloride in basic medium produced, as expected, the oxazole derivative 5. When the heating period was extended a different product, whose structure, 6, was elucidated from single-crystal X-ray diffraction.

\section{Experimental Section}

General. Melting points were determined on a Gallenkamp melting point apparatus and are uncorrected. FT-IR spectra were registered on a Perkin Elmer FT-IR 1600 using Nujol emulsions between $\mathrm{NaCl}$ plates. ${ }^{1} \mathrm{H} \mathrm{NMR}(300 \mathrm{MHz})$ and ${ }^{13} \mathrm{C}$ NMR $(75.4 \mathrm{MHz})$ spectra were recorded on a Varian Unity Plus Spectrometer at 298 K. Chemical shifts are reported in ppm relative to solvent peak or TMS; coupling constants $(J)$ are given in Hz. Double resonance, HMQC (heteronuclear multiple quantum coherence) and HMBC (heteronuclear multiple bond correlation) experiments were carried out for complete assignment of ${ }^{1} \mathrm{H}$ and ${ }^{13} \mathrm{C}$ signals in the NMR spectra. ESI mass spectrum was obtained on a LC-MS Finnigan LXQ spectrometer. High-resolution mass spectra were obtained on a Bruker FTMS APEXIII (ESI-TOF). Elemental analyses were obtained on a Leco CHNS-932 instrument.

\section{General procedure for the preparation of compounds (2a-c)}

To a solution of cyanoacetic acid $(5.0 \mathrm{~g}, 50 \mathrm{mmol})$ in $\mathrm{Ac}_{2} \mathrm{O}(50 \mathrm{~mL})$ at $50{ }^{\circ} \mathrm{C}$, indole $(5.85 \mathrm{~g}, 50$ mmol) was added. The resulting solution was heated at $85{ }^{\circ} \mathrm{C}$ for $5 \mathrm{~min}$. During that period 3cyanoacetylindole started to crystallize. The mixture was allowed to cool and the solid was collected, washed with $\mathrm{MeOH}$, and dried. The same procedure was applied with 2-methylindole to give $\mathbf{2 b}$ and with 5 -bromoindole to produce $\mathbf{2 c}$. Compounds $\mathbf{2 a}$, $\mathbf{b}$ were found to be identical to those described in the literature. ${ }^{14}$

3-(5-Bromo-1H-indol-3-yl)-3-oxopropanenitrile (2c). Pale yellow solid, Yield 85\%, mp 296$298{ }^{\circ} \mathrm{C}$, FT-IR (Nujol; in cm ${ }^{-1}$ ): $v=3205(\mathrm{NH}), 2252(\mathrm{CN}), 1634(\mathrm{CO}) ;{ }^{1} \mathrm{H}$ NMR (DMSO- $\left.d_{6}\right): \delta$ $=4.50\left(\mathrm{~s}, 2 \mathrm{H}, \mathrm{CH}_{2}\right), 7.38(\mathrm{dd}, 1 \mathrm{H}, J=8.7,1.8 \mathrm{~Hz}, \mathrm{H}-6), 7.49$ (d, 1H, J = 9.0, Hz, H-7), 8.24 (d, $1 \mathrm{H}, J=2.1 \mathrm{~Hz}, \mathrm{H}-4), 8.41(\mathrm{~s}, 1 \mathrm{H}, \mathrm{H}-2), 12.35$ (bs, $1 \mathrm{H}, \mathrm{NH}) \cdot{ }^{13} \mathrm{C}$ NMR (DMSO- $\left.d_{6}\right): \delta=29.48$ $\left(\mathrm{CH}_{2}\right), 113.87$ (C-3), 114.57 (C-7), 115.07 (C-Br), $116.21(\mathrm{CN}), 123.11(\mathrm{C}-2), 125.94(\mathrm{C}-6)$, 126.88 (C-3a), 135.38 (C-7a), 136.55 (C-4), 183.10 (CO). Anal. Calcd. (in \%) for $\mathrm{C}_{11} \mathrm{H}_{7} \mathrm{BrN}_{2} \mathrm{O}$ (263.09): C, 50.22; H, 2.68; N, 10.65. Found: C, 50.10; H, 2.78; N, 10.65.

\section{General procedure to prepare compounds (3a-c)}

A mixture of $\mathbf{2 a - c}(10 \mathrm{mmol})$ and DMFDMA $(11 \mathrm{mmol})$ was stirred for $5 \mathrm{~min}$. at room temperature, and the yellow solid that formed was filtered off and crystallized from EtOH to afford 3a-c in $78-88 \%$ yield. Compound 3a was found to be identical to that previously described in the literature. 5 
3-(Dimethylamino)-2-(1H-indole-3-carbonyl)acrylonitrile (3a). Yellow crystals, yield 78\%, mp 170-171 ${ }^{\circ} \mathrm{C}\left(\right.$ lit $\left.^{5} . \mathrm{mp} 160-163{ }^{\circ} \mathrm{C}\right) ; \delta=3.26\left(\mathrm{~s}, 3 \mathrm{H}, \mathrm{CH}_{3}\right), 3.35\left(\mathrm{~s}, 3 \mathrm{H}, \mathrm{CH}_{3}\right), 7.13(\mathrm{td}, 1 \mathrm{H}, J=$ 1.2, $6.9 \mathrm{~Hz}, \mathrm{H}-5), 7.18$ (td, 1H, $J=6.9 \mathrm{~Hz}, \mathrm{H}-6), 7.46$ (dd, 1H, J = 7.8, 2.1 Hz, H-7), 7.99 (s, 1H, $=\mathrm{CH}), 8.13(\mathrm{dd}, 1 \mathrm{H}, J=7.5,2.1 \mathrm{~Hz}, \mathrm{H}-4), 8.27(\mathrm{~d}, 1 \mathrm{H}, \mathrm{J}=3 \mathrm{~Hz}, \mathrm{H}-2),, 11.75(\mathrm{~s}, 1 \mathrm{H}, \mathrm{NH}) .{ }^{13} \mathrm{C}$ NMR (DMSO-d $\left.)_{6}\right): \delta=38.51\left(\mathrm{CH}_{3}\right), 47.39\left(\mathrm{CH}_{3}\right), 77.62(\underline{\mathrm{C}}-\mathrm{CN}), 111.70(\mathrm{C}-7), 114.70(\mathrm{C}-3)$, 121.12 (C-5), 121.75 (C-4 or CN), 121.78 (C-4 or CN), 122.49 (C-6), 126.77 (C-3a), 131.14 (C2), 135.83 (C-7a), 158.67 (=CH), 181.74 (CO).

3-(Dimethylamino)-2-(2-methyl-1H-indole-3-carbonyl)acrylonitrile (3b). Yellow crystals, yield 85\%, mp 192-193 ${ }^{\circ} \mathrm{C}$, FT-IR (Nujol; in $\mathrm{cm}^{-1}$ ): $v=3274(\mathrm{NH}), 2225(\mathrm{CN}), 1689(\mathrm{CO}) ;{ }^{1} \mathrm{H}$ NMR (DMSO- $\left.d_{6}\right): \delta=2.48\left(\mathrm{~s}, 3 \mathrm{H}, \mathrm{CH}_{3}\right), 3.19\left(\mathrm{~s}, 3 \mathrm{H}, \mathrm{N}-\mathrm{CH}_{3}\right), 3.35$ (s, 3H, N-CH $\left.{ }_{3}\right), 7.00-7.11$ (m, 2H, H-5, 6), 7.32 (dd, 1H, J = 6.9, 2.1 Hz, H-7), 7.56 (dd, 1H, J = 6.9, 2.1 Hz, H-4), 7.74 (s, $1 \mathrm{H},=\mathrm{CH}), 11.54(\mathrm{~s}, 1 \mathrm{H}, \mathrm{NH}) .{ }^{13} \mathrm{C}$ NMR $\left(\mathrm{DMSO}-d_{6}\right): \delta=13.51\left(\mathrm{CH}_{3}\right), 38.44$ and $47.09(2 \times \mathrm{N}-$ $\left.\mathrm{CH}_{3}\right), 81.38$ ( $\left.\underline{\mathrm{C}}-\mathrm{CN}\right), 110.88$ (C-7), 112.90 (C-2), 119.68 (C-4), 120.03 (CN and C-5 or C6), 121.19 (C-5 or C-6), 126.91 (C-3a), 134.77 (C-7a), 139.69 (C-3), 158.53 (=CH), 185.49 (CO). Anal. Calcd. (in \%) for $\mathrm{C}_{15} \mathrm{H}_{15} \mathrm{~N}_{3} \mathrm{O}$ (253.30); C, 71.13; H, 5.97; N, 16.59. Found: C, 70.93; H, $6.00 ; \mathrm{N}, 16.66$.

2-(5-Bromo-1H-indole-3-carbonyl)-3-(dimethylamino)acrylonitrile (3c). Yellow crystals, Yield 88\%, mp 252-254 ${ }^{\circ} \mathrm{C}$, FT-IR (Nujol; in $\mathrm{cm}^{-1}$ ): $v=3285(\mathrm{NH}), 2227(\mathrm{CN}), 1664(\mathrm{CO}) ;{ }^{1} \mathrm{H}$ NMR (DMSO- $\left.d_{6}\right): \delta=3.27\left(\mathrm{~s}, 3 \mathrm{H}, \mathrm{CH}_{3}\right), 3.31$ (s, 3H, $\left.\mathrm{CH}_{3}\right), 7.30$ (dd, 1H, $J=8.7,1.8 \mathrm{~Hz}, \mathrm{H}-6$ ), 7.45 (d, 1H, J = 9.0 Hz, H-7), 7.99 (s, 1H, =CH), 8.28 (d, 1H, J=1.8 Hz, H-4), 8.32 (s, 1H, H2), 11.92 (bs, $1 \mathrm{H}, \mathrm{NH}).) .{ }^{13} \mathrm{C}$ NMR (DMSO- $\left.d_{6}\right): \delta=47.49$ and 38.57 (2 x CH3), 77.36 ( $\underline{\mathrm{C}}-\mathrm{CN}$ ), 113.94 (C-3 or C-5), 114.02 (C-5 or C-3), 114.22 (C-7), 121.64 (CN), 123.95 (C-4), 125.06 (C6), 128.59 (C-3a), 132.33 (C-2), 134.57 (C-7a), 158.75 (C-2), 181.42 (CO). Anal. Calcd. (in \%) for $\mathrm{C}_{14} \mathrm{H}_{12} \mathrm{BrN}_{3} \mathrm{O}$ (318.17): C, 52.85; H, 3.80; N, 13.21. Found: C, 52.86; H, 3.98; N, 13.21.

\section{General procedure to prepare meridianin derivatives (4a-c)}

A mixture of enaminonitrile 3a-c $(10 \mathrm{mmol})$, guanidine hydrochloride $(12.0 \mathrm{mmol})$, anhydrous $\mathrm{K}_{2} \mathrm{CO}_{3}(2.0 \mathrm{~g}, 15.0 \mathrm{mmol})$, and absolute ethanol $(20 \mathrm{~mL})$ was heated at reflux for $7 \mathrm{~h}$. After cooling, the mixture was poured into ice-water and the solid formed was filtered off to afford $5^{\prime}$ cyano-meridianin derivatives $\mathbf{4 a - c}$ as yellow solids. Recrystallization from EtOH led to overall yields of $70-78 \%$. Spectral data for compound $\mathbf{4 a}$ are in good agreement with those reported in the literature. ${ }^{5}$

2-Amino-4-(1H-indol-3-yl)pyrimidine-5-carbonitrile (4a). Off white solid powder (70\%), mp 257-258 ${ }^{\circ} \mathrm{C}$ (lit. ${ }^{5} \mathrm{mp} 258-259{ }^{\circ} \mathrm{C}$ ). ${ }^{1} \mathrm{H}$ NMR (DMSO- $d_{6}$ ): $\delta=7.12-7.27$ (m, 2H, H-5', 6'), 7.50 (d, 1H, J = 7.5 Hz, H-7'), 7.54 and 7.64 (2 bs, 2H, NH$)_{2}$ ), 8.47 (s, 1H, H-6), 8.57 (s, 1H, H-2'), $8.65\left(\mathrm{~d}, 1 \mathrm{H}, \mathrm{J}=7.2 \mathrm{~Hz}, \mathrm{H}-4^{\prime}\right), 11.95$ (bs, $\left.1 \mathrm{H}, \mathrm{NH}\right) .{ }^{13} \mathrm{C}$ NMR (DMSO- $\left.d_{6}\right): \delta=89.23(\mathrm{C}-5)$, 111.56 (C-3'), 112.04 (C-7'), 119.82 (CN), 121.09 (C-5'), 122.80 (C-6'), 123.27 (C-4'), 125.73 (C-3’a), 130.04 (C-2’), 136.36 (C-7’’a), 163.14 (C-4 or C-2), 163.17 (C-2 or C-4), 165.35 (C-6).

2-Amino-4-(2-methyl-1H-indol-3-yl)pyrimidine-5-carbonitrile (4b). Yellow powder (74\%), mp 280-282 ${ }^{\circ} \mathrm{C}$, FT-IR (Nujol; in $\left.\mathrm{cm}^{-1}\right): v=3295(\mathrm{NH}), 3150\left(\mathrm{NH}_{2}\right), 2215(\mathrm{CN}) ;{ }^{1} \mathrm{H}$ NMR 
(DMSO- $\left.d_{6}\right): \delta=2.51\left(\mathrm{~s}, 3 \mathrm{H}, \mathrm{CH}_{3}\right), 7.02-7.14\left(\mathrm{~m}, 2 \mathrm{H}, \mathrm{H}-5^{\prime}, 6^{\prime}\right), 7.34-7.36\left(\mathrm{~m}, 1 \mathrm{H}, \mathrm{H}-7^{\prime}\right), 7.59-$ 7.61 (m, 1H, H-4'), 7.64 (s, 2H, NH ), 8.65 (s, 1H, H-6), 11.64 (s, 1H, NH). ${ }^{13} \mathrm{C}$ NMR (DMSO$\left.d_{6}\right): \delta=13.82\left(\mathrm{CH}_{3}\right), 94.40(\mathrm{C}-5), 109.72\left(\mathrm{C}-3^{\prime}\right), 110.94\left(\mathrm{C}-7^{\prime}\right), 118.40(\mathrm{CN}), 119.51\left(\mathrm{C}^{\prime} 4^{\prime}\right)$, 119.78 (C-5’), 121.47 (C-6’), 126.35 (C-3’a), 135.15 (C-7’a), 137.95 (C-2’), 163.17 (C-4 or C2), 163.28 (C-2 or C-4), 165.37 (C-6). Anal. Calcd. (in \%) for $\mathrm{C}_{14} \mathrm{H}_{11} \mathrm{~N}_{5}$ (249.27): C, 67.46; H, 4.45; N, 28.10. Found: C, 67.38; H, 4.52; N, 28.15.

2-Amino-4-(5-bromo-1H-indol-3-yl)pyrimidine-5-carbonitrile (4c). Yellow crystals (78\%), mp 325-327 ${ }^{\circ} \mathrm{C}$, FT-IR (Nujol; in cm $\left.{ }^{-1}\right): v=3428(\mathrm{NH}), 3290,3148\left(\mathrm{NH}_{2}\right), 2211(\mathrm{CN}) ;{ }^{1} \mathrm{H}$ NMR (DMSO- $\left.d_{6}\right): \delta=7.34-7.36$ (m, 1H, H-6'), 7.47-7.49 (m, 1H, H-7’), 7.57, 7.81 (bs, 2H, NH${ }_{2}$ ), 8.49 (s, 1H, H-2'), 8.57 (s, 1H, H-6), 8.75 (d, 1H, H-4'), 12.10 (bs, 1H, NH). ${ }^{13} \mathrm{C}$ NMR (DMSO-

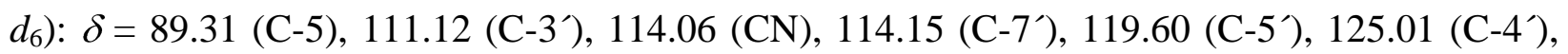
125.51 (C-6’), 127.30 (C-3’a), 131.18 (C-2’), 135.12 (C-7’a), 162.74 (C-4 or C-2), 163.11 (C-2 or C-4), 163.41 (C-6). Anal. Calcd. (in \%) for $\mathrm{C}_{13} \mathrm{H}_{8} \mathrm{BrN}_{5}$ (314.14): C, 49.70; H, 2.57; N, 22.29. Found: C, 49.35; H, 2.68; N, 22.10.

(5-Amino-isoxazol-4-yl)-(1H-indol-3-yl)-methanone (5). A mixture of enaminonitrile 3a (100.5 mg, $0.42 \mathrm{mmol})$ and anhydrous $\mathrm{K}_{2} \mathrm{CO}_{3}(84 \mathrm{mg}, 0.61 \mathrm{mmol})$ in absolute ethanol $(20 \mathrm{~mL})$ was stirred for $10 \mathrm{~min}$. at room temperature. Hydroxylamine hydrochloride $(0.5 \mathrm{mmol})$ was added and the mixture was warmed at $60{ }^{\circ} \mathrm{C}$ for $30 \mathrm{~min}$, cooled, poured into ice-water, and extracted with diethyl ether $(3 \times 50 \mathrm{~mL})$. The combined extracts were dried $\left(\mathrm{MgSO}_{4}\right)$ and the solvent was evaporated to give compound 5 as an off-white solid (25 mg, 29\%) $\mathrm{mp}$ 217.0-219.5 ${ }^{\circ} \mathrm{C} ;{ }^{1} \mathrm{H}$ NMR (DMSO-d $)_{\text {) }}$ 7.10-7.24 (m, 2H, H-5' and 6'), 7.46 (d, J=7.0 Hz, 1H, H-7'), 8.16-8.20 (s, 2H, $\mathrm{NH}_{2}$, exchangeable with $\left.\mathrm{D}_{2} \mathrm{O}\right), 8.24$ (d, 1H, $\left.J=7.0 \mathrm{~Hz}, \mathrm{H}-4^{\prime}\right), 8.31\left(1 \mathrm{H}, \mathrm{d}, \mathrm{J}=3 \mathrm{~Hz}, \mathrm{H}-2^{\prime}\right.$ ), $8.97(1 \mathrm{H}, \mathrm{s}, \mathrm{H}-3), 11.95$ (bs, $1 \mathrm{H}, \mathrm{NH}$, exchangeable with $\left.\mathrm{D}_{2} \mathrm{O}\right) .{ }^{13} \mathrm{C}$ NMR (DMSO-d $): \delta=94.30$ (C-4), 115.38 (C-3'), 111.99 (C-7’), 121.32 (C-5’), 121.54 (C-4'), 122.70 (C-6’), 126.28 (C-3’a), 131.40 (C-2'), 136.26 (C-7’a), 149.82 (C-3), 171.49 (C-5), 180.89 (CO). ESI-TOF, $\mathrm{C}_{12} \mathrm{H}_{10} \mathrm{~N}_{3} \mathrm{O}_{2}$ $\left(\mathrm{M}^{+}+1\right)$ Calc: 228.07675 ; Found: 228.07675 .

\section{General procedure to prepare compounds 6 and 7.}

A mixture of enaminonitrile $\mathbf{3 a}(10 \mathrm{mmol})$, hydroxylamine hydrochloride $\mathbf{6}$ or $p$-methoxyphenyl hydrazine hydrochloride $7(12.0 \mathrm{mmol})$, anhydrous $\mathrm{K}_{2} \mathrm{CO}_{3}(2.0 \mathrm{~g}, 15.0 \mathrm{mmol})$, and absolute ethanol $(20 \mathrm{~mL})$ was heated at reflux for $7 \mathrm{~h}$. After cooling, the mixture was poured into icewater and the resulting solid was filtered off and recrystallized from $\mathrm{EtOH}$.

2-Cyano-3-hydroxy-3-(1H-indol-3-yl)-acrylic acid (6). Brown crystals (81\%), mp 235-237 ${ }^{\circ} \mathrm{C}$, FT-IR (Nujol): $v=3399,3256(\mathrm{NH}), 2208(\mathrm{CN}), 1641(\mathrm{CO}) \mathrm{cm}^{-1} ;{ }^{1} \mathrm{H}$ NMR (DMSO- $\left.d_{6}\right): \delta=$ 7.19 (dt, 1H, H-5'), 7.24 (dt, 1H, J= 7.2 and $\left.1.2 \mathrm{~Hz}, \mathrm{H}-6^{\prime}\right), 7.53$ (d, 1H, J = 7.5Hz, H-7'), 7.608.40 (br s, $1 \mathrm{H}, \mathrm{OH}, \mathrm{D}_{2} \mathrm{O}$ exchangeable), 8.10 (d, $\left.1 \mathrm{H}, J=7.5 \mathrm{~Hz}, \mathrm{H}-4^{\prime}\right), 8.48$ (d, 1H, $J=3.2 \mathrm{~Hz}$, $\mathrm{H}-2^{\prime}$ ), 12.20 (s, $1 \mathrm{H}, \mathrm{NH}, \mathrm{D}_{2} \mathrm{O}$ exchangeable). ${ }^{13} \mathrm{C}$ NMR (DMSO- $\left.d_{6}\right): \delta=69.53$ (C-2), 109.30 (C3’), 112.55 (C-7’), $119.19(\mathrm{CN}), 121.91$ (C-5’) 121.96 (C-4’), 123.10 (C-6’), 125.59 (C-3’a), 132.28 (C-2’), 135.98 (C-7’a), 173.96 (C-1), 181.55 (C-3). ESI'-MS: 208.17 ([M-1] $\left.{ }^{+}\right)$. Anal. 
Calcd. (in \%) for $\mathrm{C}_{12} \mathrm{H}_{7} \mathrm{~N}_{3} \mathrm{O}$ (209.20): C, 68.89; H, 3.37; N, 20.09. Found: C, 68.45; H, 3.27; N, 20.39 .

(5-Amino-1-(4-methoxyphenyl)-1H-pyrazol-4-yl)(1H-indol-3-yl)methanone (7). Brown crystals (81\%), mp 230-232 ${ }^{\circ} \mathrm{C}$, FT-IR (Nujol): $v=3278(\mathrm{NH}), 1650(\mathrm{CO}), \mathrm{cm}^{-1}$; ${ }^{1} \mathrm{H}$ NMR (DMSO- $\left.d_{6}\right): \delta=3.82\left(\mathrm{~s}, 3 \mathrm{H}, \mathrm{OCH}_{3}\right), 6.81$ (s, 2H, NH ), 7.10 (d, 2H, $J=9.0 \mathrm{~Hz},\left(\mathrm{H}-3^{\prime \prime}, 5^{\prime \prime}\right)$, 7.14-7.22 (m, 2H, H-5', 6’), 7.45-7.47 (m, 1H, H-7'), 7.49 (d, 2H, J = 9.0 Hz, (H-2"“,6') 8.13 (s, 1H, H-3), 8.23-8.25 (m, 1H, H-4'), 8.29 (d, 1H, J = 2.7 Hz, H-2'), $11.86(\mathrm{~s}, 1 \mathrm{H}, \mathrm{NH}) .{ }^{13} \mathrm{C}$ NMR (DMSO- $\left.d_{6}\right): \delta=55.47\left(\mathrm{OCH}_{3}\right), 104.09(\mathrm{C}-4), 111.88\left(\mathrm{C}-7^{\prime}\right), 114.58\left(\mathrm{C}-3^{\prime \prime}, 5^{\prime \prime}\right), 115.97$ (C-3’), 121.05 (C-5’), 121.56 (C-4’), 122.51 (C-6’), 125.52 (C-2”,6”), 126.40 (C-3`a), 130.67 (C-1') 131.03 (C-2'), 136.22 (C-7'a), 139.96 (C-3), 150.40 (C-5), 158.47 (C-4'”), 182.94 (CO). ESI ${ }^{+}$-MS: $333.33\left([\mathrm{M}+1]^{+}\right)$. Anal. Calcd. (in \%) for $\mathrm{C}_{19} \mathrm{H}_{16} \mathrm{~N}_{4} \mathrm{O}_{2}(332.36)$ : C, 68.66; H, 4.85; N, 16.86. Found: C, 68.49; H, 5.00; N, 16.86.

6-(1H-Indol-3-yl)-2-oxo-1,2-dihydropyridine-3,5-dicarbonitrile (10). To a mixture of enaminonitrile 3a $(10 \mathrm{mmol})$ and malononitrile $(0.66 \mathrm{~g} ; 10 \mathrm{mmol})$ in ethanol $(15 \mathrm{~mL})$ piperidine $(0.2 \mathrm{~mL})$ was added. The reaction mixture was refluxed for $3 \mathrm{~h}$ and was then left to cool to room temperature. The precipitated product was collected by filtration and crystallized from ethanol to afford 10 as brown crystals in $75 \%$ yield. mp 198-200 ${ }^{\circ} \mathrm{C}$, FT-IR (Nujol): $v=3266(\mathrm{NH}), 22211$ $(\mathrm{CN}), 1634(\mathrm{CO}), \mathrm{cm}^{-1} ;{ }^{1} \mathrm{H}$ NMR (DMSO- $\left.d_{6}\right): \delta=7.18-7.29$ (m, 2H, H-5', 6') , 7.52-7.55 (m, 1H, H-7'), 7.72 (d, 1H, $J=7.2 \mathrm{~Hz}, \mathrm{H}-4^{\prime}$ ), 8.14 (d, 1H, $J=3.0 \mathrm{~Hz}, \mathrm{H}-2^{\prime}$ ), 8.59 (s, 1H, H-4), 12.24 (s, $1 \mathrm{H}, \mathrm{NH}$ indole), 13.10 (bs, $1 \mathrm{H}, \mathrm{NH}) .{ }^{13} \mathrm{C}$ NMR (DMSO- $\left.d_{6}\right): \delta=88.71(\mathrm{C}-5), 99.55$ (C-3), 106.14 (C-3'), 122.58 (C-7’), $115.44(\mathrm{CN}), 116.96(\mathrm{CN}), 120.46$ (C-4'), 121.0 (C-5'), 122.97 (C-6'), 124.16 (C-3’a), 131.11 (C-2'), 136.31 (C-7’a), 150.53 (C-4), 155.05 (C-6), 160.17 (CO). ESI'MS: $259.10\left([\mathrm{M}-1]^{+}\right)$. Anal. Calcd. (in \%) for $\mathrm{C}_{15} \mathrm{H}_{8} \mathrm{~N}_{4} \mathrm{O}$ (260.25): C, 69.23; H, 3.10; N, 21.53. Found: C, 69.09; H, 3.41; N, 21.68.

3-Amino-4,4,4-trichloro-2-(1H-indole-3-carbonyl)but-2-enenitrile (11). To a solution of 2a (10 $\mathrm{mmol})$ in ethanol $(25 \mathrm{ml})$ and sodium acetate $(4.1 \mathrm{~g}, 50 \mathrm{mmol})$, trichloroacetonitrile $(4.33 \mathrm{~g}, 30$ mmol) was added. The reaction mixture was stirred for $48 \mathrm{~h}$ and then poured into water, and the solid product was filtered off and crystallized from dimethylformamide to give $\mathbf{9}$ as a brown powder (74\%), mp 212-214 ${ }^{\circ} \mathrm{C}$, FT-IR (Nujol): $v=3279(\mathrm{NH}), 2215(\mathrm{CN}), 1620(\mathrm{CO}), \mathrm{cm}^{-1} ;{ }^{1} \mathrm{H}$ NMR (DMSO- $\left.d_{6}\right): \delta=7.18-7.24\left(\mathrm{~m}, 2 \mathrm{H}, \mathrm{H}-5^{\prime}, 6^{\prime}\right)$ ) 7.48-7.51 (m, 1H, H-7'), 8.16-8.18 (m, 1H, $\left.\mathrm{H}^{-} 4^{\prime}\right), 8.47$ (d, 1H, $\left.J=3.2 \mathrm{~Hz}, \mathrm{H}-2^{\prime}\right), 9.42$ (bs, 1H, NH), 11.98 (s, 2H, NH${ }_{2}$ ). ${ }^{13} \mathrm{C}$ NMR (DMSO$\left.d_{6}\right): \delta=76.10(\mathrm{C}-2) 91.61\left(\mathrm{C}-4, C C l_{3}\right), 112.22\left(\mathrm{C}^{\prime} 7^{\prime}\right), 114.52\left(\mathrm{C}-3^{\prime}\right), 119.80(\mathrm{CN}), 121.76(\mathrm{C}-$ 5’), 121.78 (C-4’), 122.92 (C-6’), 126.54 (C-3’a), 132.28 (C-2'), 135.77 (C-7’a), 167.41 (C-3), 185.45 (CO). ESI-MS: $326.17\left({ }^{35} \mathrm{Cl},[\mathrm{M}-1]^{+}\right), 328.08\left({ }^{35} \mathrm{Cl}(2),{ }^{37} \mathrm{Cl},[\mathrm{M}-1]+\right), 330.00\left({ }^{35} \mathrm{Cl}\right.$, ${ }^{37} \mathrm{Cl}(2)[\mathrm{M}-1]^{+}$). Anal. Calcd. (in \%) for $\mathrm{C}_{13} \mathrm{H}_{8} \mathrm{Cl}_{3} \mathrm{~N}_{3} \mathrm{O}$ (328.58): C, 47.52; H, 2.45; N, 12.79 . Found: C, 47.26; H, 2.85; N, 12.81 .

Ethyl 2-cyano-3-(1H-indol-3-yl)acrylate (13). To a solution of 3-formylindole (10 mmol) in ethanol $(25 \mathrm{ml})$ and ethylcyanoacetate $(10 \mathrm{mmol})$, and piperidine $(0.2 \mathrm{~mL})$ was added. The reaction mixture was refluxed for $2 \mathrm{~h}$ and then left to cool to room temperature. The solid that precipitated was filtered off and recrystallized from ethanol to give $\mathbf{1 3}$ as yellow crystals in $\mathbf{9 2 \%}$ 
yield. mp 170-171 ${ }^{\circ} \mathrm{C}$, FT-IR (Nujol): $v=3278(\mathrm{NH}), 2224(\mathrm{CN}), 1680(\mathrm{CO}), \mathrm{cm}^{-1} ;{ }^{1} \mathrm{H}$ NMR $\left(\mathrm{CDCl}_{3}\right): \delta=1.41\left(\mathrm{t}, 3 \mathrm{H}, J=7.2 \mathrm{~Hz}, \mathrm{CH}_{3}\right), 4.38\left(\mathrm{q}, 2 \mathrm{H}, J=7.2 \mathrm{~Hz}, \mathrm{CH}_{2}\right), 7.32-7.36(\mathrm{~m}, 2 \mathrm{H}, \mathrm{H}-$ $\left.5^{\prime}, 6^{\prime}\right), 7.48-7.51\left(\mathrm{~m}, 1 \mathrm{H}, \mathrm{H}-7^{\prime}\right), 7.84-7.86\left(\mathrm{~m}, 1 \mathrm{H}, \mathrm{H}-4^{\prime}\right), 8.64$ (s, 1H, =CH), 8.67 (d, 1H, J = 3.3 $\left.\mathrm{Hz}, \mathrm{H}-2^{\prime}\right), 9.24(\mathrm{bs}, 1 \mathrm{H}, \mathrm{NH}) .{ }^{13} \mathrm{C} \mathrm{NMR}\left(\mathrm{CDCl}_{3}\right): \delta=14.30(\mathrm{CH} 3), 62.04(\mathrm{CH} 2), 94.93(\mathrm{C}-2)$, 111.23 (C-3'), 112.20 (C-7'), 118.13 (CN), 118.33 (C-4'), 122.65 (C-5'), 124.23 (C-6’), 127.39 (C-3’a), 130.68 (C-2'), 135.60 (C-7’a), 146.55 (C-3’), 163.76 (C-1). Anal. Calcd. (in \%) for $\mathrm{C}_{14} \mathrm{H}_{12} \mathrm{~N}_{2} \mathrm{O}_{2}$ (240.26): C, 69.99; H, 5.03; N, 11.66. Found: C, 69.97; H, 5.16; N, 11.86.

2-Amino-6-(1H-indol-3-yl)-4-oxo-1,4-dihydropyrimidine-5-carbonitrile (14). A mixture of 13 (10 mmol), guanidine hydrochloride $(12.0 \mathrm{mmol})$, anhydrous $\mathrm{K}_{2} \mathrm{CO}_{3}(2.0 \mathrm{~g}, 15.0 \mathrm{mmol})$, and absolute ethanol $(20 \mathrm{~mL})$ was heated at reflux temperature for $7 \mathrm{~h}$. After cooling, the mixture was poured into ice-water and neutralized with acetic acid. A solid product formed which was filtered off and recrystallized from EtOH to afford $\mathbf{1 4}$ as a yellow solid in $77 \%$ yield. mp 252$253{ }^{\circ} \mathrm{C}$, FT-IR (Nujol): $v=3327(\mathrm{NH}), 2211(\mathrm{CN}), 1659(\mathrm{CO}), \mathrm{cm}^{-1} ;{ }^{1} \mathrm{H}$ NMR (DMSO- $\left.d_{6}\right): \delta=$ 7.10-7.22 (m, 4H, H-5', 6’ $\mathrm{NH}_{2}$ ), 7.47 (d, 1H, J = 8.4 Hz, H-7’), 8.44 (d, 1H, J = $3.0 \mathrm{~Hz}, \mathrm{H}-2^{\prime}$ ), 8.57 (d, 1H, $\left.J=7.5 \mathrm{~Hz}, \mathrm{H}-4^{\prime}\right), 11.31$ (s, $1 \mathrm{H}, \mathrm{NH}$ indole), 11.92 (s, 1H, NH). ${ }^{13} \mathrm{C}$ NMR (DMSO$\left.d_{6}\right): \delta=79.40(\mathrm{C}-5) 111.77\left(\mathrm{C}^{\prime} 3^{\prime}\right), 111.96\left(\mathrm{C}^{\prime} 7^{\prime}\right), 119.28(\mathrm{CN}), 120.88\left(\mathrm{C}-5^{\prime}\right), 122.54\left(\mathrm{C}^{\prime} 6^{\prime}\right)$, 123.51 (C-4’), 126.13 (C-3’a), 130.51 (C-2’), 136.25 (C-7’a), 155.98 (C-2), 162.21 (CO), 166.67 (C-6). ESI-MS: $250.08\left([\mathrm{M}-1]^{+}\right)$. Anal. Calcd. (in \%) for $\mathrm{C}_{13} \mathrm{H}_{9} \mathrm{~N}_{5} \mathrm{O}$ (251.24): C, 62.15; H, 3.61; N, 27.87. Found: C, 62.40; H, 3.26; N, 27.77.

\section{Single-crystal X-ray Diffraction}

A single-crystal of compound $\mathbf{6}$ was manually harvested from the crystallization vial and mounted on a Hampton Research CryoLoop using FOMBLIN Y perfluoropolyether vacuum oil (LVAC 25/6) purchased from Aldrich ${ }^{20}$ with the help of a Stemi 2000 stereomicroscope equipped with Carl Zeiss lenses. Data were collected at 150(2) K on a Bruker X8 Kappa APEX II charge-coupled device (CCD) area-detector diffractometer (Mo $\mathrm{K}_{\alpha}$ graphite-monochromated radiation, $\lambda=0.71073 \AA$ ) controlled by the APEX2 software package, ${ }^{21}$ and equipped with an Oxford Cryosystems Series 700 cryostream monitored remotely using the software interface Cryopad. $^{22}$ Images were processed using the software package SAINT,$+{ }^{23}$ and data were corrected for absorption by the multi-scan semi-empirical method implemented in SADABS. ${ }^{24}$ The crystal structure was solved by employing the direct methods implemented in SHELXS-97..$^{25,26}$ This strategy allowed the immediate location of the vast majority of the atoms. All the remaining non-hydrogen atoms were directly located from difference Fourier maps calculated from successive full-matrix least squares refinement cycles on $F^{2}$ using SHELXL-97. ${ }^{26,27}$ All non-hydrogen atoms have been successfully refined using anisotropic displacement parameters.

Hydrogen atoms bound to carbon/nitrogen and oxygen were placed at their idealized positions using the HFIX 43 or 147 instructions in SHELXL and included in subsequent refinement cycles in riding-motion approximation with isotropic thermal displacements parameters $\left(U_{\text {iso }}\right)$ fixed at 1.2 or $1.5 \times U_{e q}$ of the carbon/nitrogen or oxygen atom to which they are attached, respectively. 
The last difference Fourier map synthesis showed the highest peak $\left(0.494 \mathrm{e}^{-3}\right)$ and deepest hole $\left(-0.635 \mathrm{e}^{-3}\right)$ located at $0.40 \AA$ and $0.51 \AA$ from $\mathrm{O} 1$ and $\mathrm{O} 2$, respectively.

Crystal data: $\mathrm{C}_{12} \mathrm{H}_{8} \mathrm{~N}_{2} \mathrm{O}_{3}, M=228.20$, monoclinic, space group $C 2 / \mathrm{c}, Z=8, a=27.964(6) \AA$, $b=5.3241(11) \AA, c=17.278(4) \AA, \beta=124.186(19)^{\circ}, V=2127.9(8) \AA^{3}, \mu\left(\mathrm{Mo}_{\mathrm{K} \alpha}\right)=0.105 \mathrm{~mm}^{-1}$, $D_{\mathrm{c}}=1.425 \mathrm{~g} \mathrm{~cm}^{-3}$, brown prism with crystal size of $c a .0 .25 \times 0.20 \times 0.20 \mathrm{~mm}^{3}$. Of a total of 39590 reflections collected, 2856 were independent $\left(R_{\text {int }}=0.0308\right)$. Final $R 1=0.0602[I>2 \sigma(I)]$ and $w R 2=0.2172$ (all data). Data completeness to theta $=29.13^{\circ}, 99.6 \%$.

Crystallographic data (excluding structure factors) for compound 6 have been deposited with the Cambridge Crystallographic Data Centre as supplementary publication no. CCDC-816317. Copies of the data can be obtained free of charge on application to CCDC, 12 Union Road, Cambridge CB2 2EZ, U.K. Fax: (+44) 1223 336033. E-mail: deposit@ ccdc.cam.ac.uk.

\section{Acknowledgements}

We are grateful to Fundação para a Ciência e a Tecnologia and FEDER (POCTI-SFA-3-686, for general financial support; REEQ/ 630/QUI/2005, for LCMS; and specific funding for the purchase of the single-crystal diffractometer). We also acknowledge FCT for funds to support the NMR spectrometer as part of the National NMR Network (RNRMN). Thanks are due also for the post-doctoral research grant to A. Salaheldin (SFRH/BPD/31490/2006). We further thank Miss Elisa Pinto for obtaining the NMR and elemental analyses data, and Miss Natércia Nunes for LCMS determinations.

\section{References}

1. Salaheldin, A. M.; Alphy, M. K. J. Heterocycl. Chem. 2008, 45, 307.

2. Franco, L. H.; Joffe, E. B. K.; Puricelly, L.; Tatian, M.; Seldes, A. M.; Palermo, J. A. J. Nat. Prod. 1998, 61, 1130.

3. Franco, L. H.; Palermo, J. A. Chem. Pharm. Bull. 2003, 51, 975.

4. Gompel, M.; Leost, M.; Bal de Kier Joffe`, E.; Puricelli, L.; Franco, L. H.; Palermo, J.; Meijer, L. Bioorg. Med. Chem. Lett. 2004, 14, 1703.

5. Radwan, M. A. A.; El-Sherbiny, M. Bioorg. Med. Chem. 2007, 15, 1206.

6. Jiang, B.; Yang, C.-G. Heterocycles 2000, 53, 1489.

7. Bredereck, H.; Effenberger, F.; Botsch, H.; Rehn, H. Chem. Ber. 1965, 98, 1081.

8. Fresneda, P. M.; Molina, P.; Bleda, J. A. Tetrahedron 2001, 57, 2355.

9. Karpov, A. S.; Merkul, E.; Rominger, F.;Müller, T. J. J. Angew. Chem., Int. Ed. 2005, 44, 6951.

10. Salaheldin, A. M.; Oliveira-Campos, A. M. F.; Rodrigues, L. M. Tetrahedron Lett. 2007, 48, 8819. 
11. Oliveira-Campos, A. M. F.; Salaheldin, A. M.; Rodrigues, L. M. Arkivoc 2007, (xvi), 92.

12. Salaheldin, A. M.; Oliveira-Campos, A. M. F.; Rodrigues, L. M. Arkivoc 2008, (xiv), 180.

13. Salaheldin, A. M.; Oliveira-Campos, A. M. F.; Rodrigues, L. M. Synth. Commun. 2009, 39, 1186.

14. Slatt, J.; Romero, I.; Bergman, J. Synthesis 2004, 2760.

15. US Patent 6579983, Celltech R \& D Ltd. 2000; Chem. Abstr. 2000, 134, 71598.

16. Bernstein, J.; Davis, R. E.; Shimoni, L.; Chang, N. L., Angew. Chem. Int. Edit. Engl. 1995, $34,1555$.

17. Radwan, M. A. A.; Ragab, E. A.; Shaaban, M. R.; El-Nezhawy, A. O. H. Arkivoc 2009, (vii), 281.

18. Jakše, R.; Svete, J.; Stanovnik, B.; Golobic, A. Tetrahedron 2004, 60, 4601.

19. Časar, Z.; Bevk, D; Svete, J.; Stanovnik, B. Tetrahedron 2005, 61, 7508.

20. Kottke, T.; Stalke, D. J. Appl. Cryst. 1993, 26, 615.

21. APEX2, Data Collection Software Version 2.1-RC13, Bruker AXS, Delft, The Netherlands 2006.

22. Cryopad, Remote monitoring and control, Version 1.451, Oxford Cryosystems, Oxford, United Kingdom 2006.

23. SAINT+, Data Integration Engine v. 7.23a, 1997-2005, Bruker AXS, Madison, Wisconsin, USA.

24. Sheldrick, G. M., SADABS v.2.01, Bruker/Siemens Area Detector Absorption Correction Program, 1998, Bruker AXS, Madison, Wisconsin, USA.

25. Sheldrick, G. M., SHELXS-97, Program for Crystal Structure Solution, University of Göttingen, 1997.

26. Sheldrick, G. M. Acta Cryst. A 2008, 64, 112.

27. Sheldrick, G. M., SHELXL-97, Program for Crystal Structure Refinement, University of Göttingen, 1997. 